\title{
CORRECTION
}

\section{Correction to: Size effect on branched sideways cracks in orthotropic fiber composites}

\author{
Abdullah Dönmez • Zdeněk P. Bažant $®$
}

Published online: 7 July 2020

(C) Springer Nature B.V. 2020

\section{Correction to:}

International Journal of Fracture (2020) 222:155-169 https://doi.org/10.1007/s10704-020-00439-1

1. The second line of Eq. 24 should have $\sigma_{N}^{2} / 2 \hat{E}$ in front.

2. Eq. 28b should read:

$$
Q=\left[\begin{array}{ccc}
q_{11} & 0 & 0 \\
0 & q_{22} & 0 \\
0 & 0 & q_{12}
\end{array}\right]
$$

Publisher's Note Springer Nature remains neutral with regard to jurisdictional claims in published maps and institutional affiliations.

The original article can be found online at https://doi.org/10. 1007/s10704-020-00439-1.

A. Dönmez

Ístanbul Teknik Üniversitesi, Istanbul, Turkey

e-mail: donmezab@itu.edu.tr

A. Dönmez

Northwestern University, Evanston, USA

Z. P. Bažant ( $\square)$

Civil and Mechanical Engineering and Materials Science,

Northwestern University, Evanston, USA

e-mail: z-bazant@northwestern.edu 